as member of council, foreign secretary, or president (1921-24). But fortunately, Dr. Hutchinson is retiring in excellent health, so that we may trust that his interest in the work of the Society may be long continued.

\section{Prof. A. E. Trueman}

THE chair of geology in the University of Glasgow, rendered vacant through the resignation of Prof. E. B. Bailey on his appointment as director of the Geological Survey of Great Britain, is to be filled by Prof. A. E. Trueman of the University of Bristol. Prof. Trueman was educated at High Pavement School and University College, Nottingham, and he received the degree of D.Sc. in geology from the University of London in 1918. He was appointed assistant lecturer in geology at Cardiff in 1917, and head of the Department of Geology in University College, Swansea, in 1920. In 1933 he succeeded Prof. S. H. Reynolds as Chaning Wills professor of geology in the University of Bristol. Prof. Trueman is best known by his researches in problems of Coal Measures Geology. In particular, he has taken an important part in the zoning of the Coal Measures of South Wales by means of non-marine lamellibranchs, and in their correlation with other areas. $\mathrm{He}$ has also co-operated in research work carried out on dust from coal mines, in connexion with its bearing on the problem of silicosis among miners. In addition to his purely scientific work, Prof Trueman has interested himself especially in the Workers Educational Association and other university extension activities. He is also a member of a committee appointed at Blackpool last year by Section C of the British Association to study the position of geology in the present educational system.

\section{The National Government and Democracy}

A PAMPhlet entitled "The Case for the National Government" by Earl de la Warr, chairman of the National Labour Committee, stresses the failure of democratic politicians to grapple with the problems of the new world with which the man of science is con. fronting this generation. In many countries they are unprepared for this new challenge of the scientific world, and the seriousness of the new problems and the pace at which solutions are demanded is too much for politicians either of the Left or of the Right. $\mathrm{He}$ believes that dictatorships have revived because democratic politicians have been unable or unwilling to adapt themselves to the new age and therefore have been weak and indecisive in dealing with modern problems. Earl de la Warr claims that Great Britain, in its National Government, is giving the democratic reply to conditions which have led to dictatorships elsewhere. Since we are finding our way into a new world, much of the work of the Government is necessarily experimental.

THIs new world is very largely the result of the discoveries and inventions of the chemist, the physicist, the biologist in the last hundred years or so. Science has given more to the world in that period than in any previous thousand years. Hitherto the politician has been concerned rather with the rights and liberties of man than with the possibilities of transforming everyday life by organizing the gifts of the scientific worker. The economic and social sciences have barely begun to keep pace with the physical and technical sciences. Nations should now be thinking not in terms of access to raw materials but to markets or even more of the creation of markets. The problems of to-day are the problems not of shortage as in the past but of plenty. The challenge of science cannot be met by limiting production or inventions but by dealing on rational and scientific lines with the factors which undermine national physique and welfare such as poverty, malnutrition, overcrowding. This is a matter of scientific organization whether of distribution, consumption, education or the like, and that such an approach is not easily turned into a fighting appeal to a democratic people is a real difficulty. Unless, however, democracy succeed in directing man's inherent pugnacity into fruitful and creative channels, the downfall of civilization is certain, and Earl de la Warr believes the National Government is an attempt to give a wise and courageous answer to many of these vexed questions.

\section{English Terms in Scientific Writings}

The S.P.E. Tract No. 48 (Oxford, Clarendon Press ; 1937) contains three articles that are of interest to writers on scientific subjects. Mr. Otto Jesperson deals with the use of such terms and phrases as 'almost' before a verb or noun, 'kind of' or 'sort of', 'rather than', 'as much as', and so on. Sir W. A. Craigie notes many variations in the spelling of English words, but conoludes that "the irregularities of modern English are of slight importance in relation to the language as a whole". Dr. C. G. Darwin's article on "Terminology in Physics" is reprinted from Natuke $(138,908$; 1936). His main points, it will be remembered, are : the difficulty of translating appropriately a term from a foreign language, the use of an inventor's name instead of a descriptive term, and the use of adjectives, such as 'microscopic' and 'macroscopic', to express opposite ideas by words of nearly the same sound and spelling. Others may be added to this list. For example, 'sismi', an equivalent for earthquakes, is simple to pronounce in Italian, and 'séismes' still more so in French, but the corresponding English term 'seisms' is intolerable. Another point is the formation of the singular of a word that has come down to us in the plural only. It would seem permissible, because natural and convenient, to use 'scree' as the singular of the Icelandic word 'screes'.

\section{Popularization of Science}

Is an address on the "Popularisation of Science" when receiving the fellowship of the American Institute, New York, on February 4, "for interpreting to the people of the nation the rapid progress of science upon which modern civilization depends and for the organised dissemination of research findings 
as news", Mr. Watson Davis said that the reporting and interpretation of science failed of its purpose if it did not bring about an appreciation and utilization of scientific method in everyday life. This he believed was best achieved by giving the mass of the people, through accurate and interesting accounts of science's successes and failures, some understanding of the essence of science which would lead them to apply it more widely to our everyday life, our human relationships, business and government. Many of the ideals we most cherished such as liberty, opportunity, the pursuit of happiness, freedom, democracy, were achieved by the utilization of scientific method, and the mistakes of democracy were best corrected by science.

THIs belief, that the only way of making democracy safe for itself was to make it more intelligent and accordingly more scientific, inspired the founders of Science Service, E. W. Scripps and Dr. W. E. Ritter. Many opportunities of such service were as yet only imperfectly used. For example, the scientific aspects of the recent disastrous floods had received little publicity, and the possibilities of books and magazines as media have yet to be fully developed. In this work quality is all important, and the first objective is the exact opposite of propaganda. It is to present facts in a readable and interesting form, on which the reader could base his own opinions on a subject of politics, sociology or his duty to his fellows. In recalling this statement of the founders of Science Service as to its objectives, Mr. Watson Davis emphasized that not even science must be allowed to become a dictator. It should set the example for straight thinking, confident that the process of democracy, guided by scientific method and reason, would give effective results.

\section{Development of the Oil Engine}

The millions of compression-ignition oil engines in use to-day have all sprung from the initial work of Herbert Akroyd Stuart (1864-1927) and Rudolph Diesel (1858-1913), whose outstanding patents were taken out in 1890 and 1892 respectively. Vast sums of money have been spent by Governments, firms, institutions and individuals in experiments with oil engines, but just as the first successful Diesel engine was the outcome of the work during 1893-97 of the Maschinenfabrik-Augsburg-Nurnberg, so the success of the engine invented by Akroyd Stuart-known as the "Hornsby-Akroyd" engine-was due to the pioneering work of Messrs. Hornsby and Sons, Ltd., of Grantham, now Ruston and Hornsby, Ltd., of Lincoln. Having offered his patents to various gas engine makers, Stuart approached Messrs. Hornsby, and in $\mathbf{1 8 9 1}$ they agreed to take up the development of Stuart's engine on a royalty basis. The necessary experimental work was entrusted to Mr. J. W. Young, who in a paper entitled "Notes on the Practical Development of the Oil Engine" read to the Newcomen Society on March 17, gave an interesting account of the difficulties which had to be overcome before the "Hornsby-Akroyd" engine could be placed on the market.
STUaRT's principal patents were No. 7146 of May 1890 and No. 15994 of October 1890 and these covered compression ignition and airless injection, and also the use of a vaporizer. The most difficult problem was that of combustion, and many forms of vaporizers were tried. The construction of oil engines, too, demanded a higher standard of workmanship than the steam engines, and cylinders, pistons and piston-rings were all the subject of many experiments. Both fuel oil and lubricating oil raised many problems, especially as the oil refiners of that time, had not succeeded in removing certain resinous bodies from the oil. In connexion with this, Mr. Young was sent to Russia, where Messrs. Nobel Brotbers co-operated in introducing a uniform standard of distillation. As regards the development of the "Hornsby-Akroyd" engine Stuart took no part after 1891. He migrated to Western Australia about 1900 and died there on February 19, 1927. The so-called semi-Diesel engine is properly an Akroyd-Stuart engine, and nearly all makers of Diesel engines now use his method of airless injection, and not air-blast injection as introduced by Diesel.

\section{Chair in Biblical Archæology: an Appeal}

AN appeal for funds to endow a chair in biblical archæology in connexion with the Institute of Archæology of the University of London, has been issued over the signatures of the Archbishop of Canterbury, Sir Frederic Kenyon, Sir George Hill and Sir Charles Peers, should meet with a ready and liberal response, especially as the generous gift by Sir Charles Marston of $£ 1,000$ has already reduced substantially the amount which it is considered necessary to provide. Palestine demands of the field worker a widely extended and detailed knowledge of the general cultural and historical background, owing to its geographical position and its political, economic, and cultural relations with contemporary peoples. The institution of a chair in biblical archæology, by making provision for that preliminary training in acquisition and manipulation of the historical and cultural facts of the Ancient World, should go far towards conserving the time and energy of senior members of an expedition, which must be devoted to the training and supervision of the younger workers in the field. Not only does the installation of Sir Flinders Petrie's Palestinian collections at the Institute of Archæology make this an opportune moment to inaugurate such a chair, but also the results which have been achieved by recent excavation in Palestine, as for example at Lachish, Jericho and Gaza, as well as indications of the bearing of Palestinian material on the excavations now being carried out in Syria, all point in the direction of the imminent possibility of important additions to knowledge. This should be an additional stimulus to the British public, who have always looked kindly upon research in Palestine. Contributions may be sent to Mr. E. S. M. Perowne, 7 Great James Street, Bedford Row, W.C.1, or direct to the Westminster Bank, Marylebone Branch, 1 Stratford Place, Oxford Street, W.1, marked "Institute of Archæology". 